\title{
THE CRITERIA NECESSARY IN THE SELECTION OF PEDAGOGICAL TOOLS IN RELATION TO MEDIA AND INTERNET EDUCATION
}

\author{
Birgitte Tufte, Jeanette Rasmussen ${ }^{1}$
}

\begin{abstract}
Aujourd'hui, les enfants, d'où qu'ils soient, plongent dans la culture des nouveaux médias avec la même curiosité, le même enthousiasme, qui les poussent à vouloir maîtriser la technologie. L'uniformité de leur "culture média" est une réalité non négligeable : les médias en général et Internet en particulier acquièrent actuellement une fonction éducative et socialisante, nouvelle dans l'histoire.

Le fossé entre école "établie" (savoirs formels) et "école des médias" (savoirs informels) se creuse peu à peu, l'éducation à la démocratie restant en principe un sujet "scolaire". L'école acquiert ainsi un rôle particulier par rapport aux médias et surtout par rapport à Internet, où ne domine pas encore la notion d'enseignement.

Il devient nécessaire, en classe, de partir du principe contradictoire que les enfants sont des usagers compétents, et espiègles, de la matière enseignée ; tout en gardant à l'esprit que les objectifs définitoires de l'école doivent être remplis. Il est cependant possible de se détacher quelque peu des calendrier et programme habituels, pour travailler, par exemple, à la construction de sites Web ou à l'élaboration de publicités.

Le côté "technique" des nouveaux médias est relativement facile à enseigner aux jeunes, et son intérêt réside dans le fait qu'en construisant (un site, une bannière publicitaire...) l'élève peut acquérir des instruments d'analyse supplémentaires afin de mettre en oeuvre par la suite des compétences de raisonnement, de sélectivité et d'esprit critique face à Internet.
\end{abstract}

Recherches en communication, $\mathrm{n}^{\circ} 22$ (2004). 
Au Danemark, après avoir adapté et analysé le matériel Educaunet disponible, les auteurs se sont attelés à évaluer non seulement le matériel, mais également l'utilisation qui en était faite par les professeurs. Les résultats de ces évaluations montrent que la plupart des activités ont bien fonctionné, avec les enseignants comme avec les élèves. Les enseignants, qui avaient participé à l'évaluation du matériel proprement dit, en avaient de ce fait une connaissance assez bonne. Les résultats très positifs obtenus après l'utilisation du Kit dans leurs classes les ont positivement surpris : il ne fait aucun doute qu'il est nécessaire de mettre au point des activités telles qu'Educaunet pour donner aux enseignants le matériel nécessaire à l'éducation aux médias - et spécifiquement à Internet - en classe.

\section{Why is Internet Education important ?}

No matter where they live in the world young people turn to the new media and communications culture with the same curiosity, enthusiasm and will to master the technology. The culture of children and young people is truly global when it comes to the media. And - given access - we find by and large the same patterns among young people the world over.

From at least this one point of view, the picture is relatively uniform, but there are also a great number of nuances based on geography and economy, differences depending on whether the child lives in a country rich in media and having a high level of media and communications technology - or perhaps the opposite. There are social differences, as well, based on the family's level of education and income, there are age-based differences, and not least, we find differences between how boys and girls, respectively, use the media they have access to.

For quite some years the media have been undergoing rapidly growing changes - from print media, to visual, audio-visual media and recently to the multimedia of the computer - and the Internet.

Thus the media in general and especially the Internet are in these years acquiring an educational and socialization function that is new in history.

Due to the growing globalization and commercialization of new media, it is becoming increasingly evident that it is no longer a question of communication to the enlighted citizen, as it - to a wide extent - used 
to be. It is now for the major part of media messages a goal to reach the consumer. In other words, in the construction and self perception of the media to-day there has been a shift from the idea of the media receiver as a member of the community, who is to be educated for democracy, to a view of the media receiver as a consumer.

Children and young people are - by researchers and marketers - considered as "early adopters" of new media. Although digital media are probably only in their first phase, new media play an important role for children and adolescents.

Various studies show that although TV is still the dominant media the time spent in front of the TV screen is declining, while the time spent in front of the computer is increasing, and in most countreis families with children is the group who is the fastest-growing group having access to the Internet.

Another result of many studies is that children have a growing influence on the consumption of the families in relation to a variety of products. They are not only consumers on their own - with the money they receive as pocket money or that they earn - they have also a huge influence on the total consumption of the family.

Accordingly, to-day children and young people are becoming a still more interesting target group for marketers, and the Internet is being used to reach them. Advertising on the Internet, with the use of various new techniques, is increasing, and one of the features of marketing through the Internet is the blending of what has traditionally been called "content" with advertising, the result of which is that it is difficult to define what is content and what is advertising.

Children and young people use the Internet for various purposes i.e. entertainment like games etc., for chatting, for searching for school work and to buy. E-commerce is not yet a daily phenomenon for youngsters, but it is increasing and in many countries it is discussed whether very young people should be allowed to have a credit card.

The above situation is discussed among teachers, parents, politicians, marketers and others who - for various reasons - are interested in communication to children.

Some prefer to consider the child as a competent creature who is able to act responsibly to the messages received through the media, whereas others are convinced that children are vulnerable and that we - as grown ups - have a responsibility to protect them. Maybe the truth is to be found somewhere in between - as many factors are important such as the age of the child, the surroundings, the family etc. However, 
there is general agreement that the school ought to play a role in relation to the use of digital media in the children's and adolescents everyday life.

The gap between the established school and the parallel school of the media seems to be continuously widening, because in principle the school is still subject to the notion of education for democracy.

Thus the school acquires a special role in relation to the media in general and especially in relation to the Internet where there exists a minimum of teaching.

In the everyday lives of children and the young people three factors interact : family, school and media. It is taken for granted that the three areas contribute jointly within the overall process of education, and that the importance of the family is on the wane. Accordingly, school and media gain increasing influence. It constitutes a problem that the field of the media is still relatively invisible in relation to the school and its educational tradition, in the sense that most teachers continue to define themselves as the trustees of a cultural capital, which does not incorporate the media-cultural competence of the pupils.

\section{How to practice Internet Education}

The main goal of attending school is education. Since the beginning of industrialised society, it has been crucial to discipline the labour force, and one of the main disciplinary forces has been schooling. Goal orientation, order and rationality have been, and are key concepts in attaining discipline. Children were supposed to learn something in school, and school is certainly not intended to be entertaining.

As has been said above, research shows that children and adolescents to a large extent use new media for entertainment and game purposes. Accordingly one could say that children's and young people's active media use could be defined as an escape from and protest against all the rational information presented in traditional media programmes and a reaction against the linear and goal-oriented teaching that is presented in most classrooms.

On the assumption that fascination with electronic mass media lies within the field of tension between daily life and ideas and dreams about something else it is important to discuss - and point at practices 
- how media - and in this case Internet education - can be integrated in teaching.

The rapid penetration of the Internet and other digital technologies into European families and an increasing interest in children and young people as a target market have been element in creating an explosion of digital products and services for children. What has happened during the last 10 years is that the Internet has developed from being a non-commercial, publicly funded, closed network into a privatized and increasingly commercialized global network. This is a challenge for education.

In the classroom it is important to start with the contradictions i.e. the contradiction that children are competent and playful users of new media and the fact that there are in-built goals of the school, which have to be fulfilled.

In the media and Internet teaching it is important to start with the structure of the school. It is not a law of nature to have a break every hour, or to learn about a new subject every hour. It is possible to break down the traditional timetable of the school and to work, for instance with production of Internet advertising and construction of websites. The technical part is relatively easy to learn for both boys and girls. What happens during the production process of for instance banner commercials is that children and adolescents acquire a superior analytical instrument for being reasonable, selective and critical when using the Internet.

The aim of that type of teaching is to reach an awareness based on practical activity and analytical activities. It is, however, important to emphasize that practical activity does not, in itself, constitute Internet education.

The use and culture of the Internet has to be accepted on the same premises as traditionally accepted areas of culture and communication. Just as comics have been drawn into the classroom some years ago and video production and TV analysis to some extent - at least in countries in the Northern part of Europe - has been part of the curriculum it is important to work with a combination of production and analysis in relation to the Internet teaching.

The theory behind this is that if one has some knowledge about the kind of craft skills involved in a given production process, one is better equipped to appreciate and be critically responsive to different kind of messages and types of communication. 
Accordingly, we see key concepts in Internet education as the following :

Point of departure for the teaching process is to accept that using the Internet for the majority of children and adolescents is a combination of play and learning - on their own premises.

In the classroom you have to fulfil the obligations of the curriculum, and to do that in relation to various subjects the ideal approach is to work across the curriculum - i.e. that teachers representing different topics work together. This means a cross-curricular type of teaching that combines production of for instances Internet advertising and analyses of advertising - or production of web-sites which are being analysed and compared with other websites.

In relation to these overall theories and ideas we will in the following describe the process of steps that lead to the results of the Internet education, which has taken place during the two-year period of the Educaunet project. See below figure :

\section{The development phase}

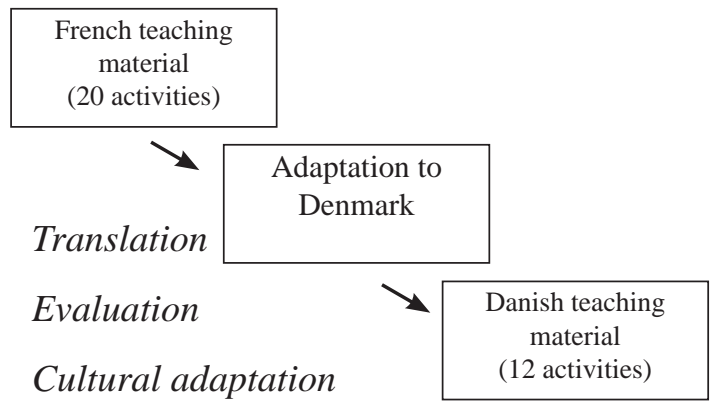

Figure 1 : From French/Belgium Internet teaching material to Danish

In order to develop the Internet teaching material based on Educaunet 1 material we, the Danish team of researchers, initially went through all the original material to leave out the activities that from our perspectives would not work in relation to the Danish school system. An example is an activity about whether to install filters on computer at home and in schools. This discussion is not very relevant in Denmark where the general attitude is to educate the children and young people about the Internet instead of banning content by filters. We then established an "expert group" of teachers/trainers, all familiar with media education and the Internet, and the leader of a media education centre to help us evaluate the material. 
First step was a line of meetings where the group read the selected material with their views on usefulness as teaching material, needed cultural adaptations and other positions on creating Internet teaching material. This task was difficult because many activities were created for the French/Belgium school system and the expert group had to imagine the activities in a Danish pedagogical context and school system. One of the main objectives, beside the teachers critically going through the original material, was also to open up for new ideas for activities. Was the original material adequate ? Or were there areas that needed special attention ? Two new ideas that came from the meetings were to create an activity about "Advertising on the Net" and "E-commerce".

The originally material had an activity that only concentrated on net advertising. The Danish expert group found that Net advertising should be a more integrated part of advertising analysis if the activity was to work in a Danish context. Print and TV-ads analysis is already a part of the curriculum in the subject Danish. The expert group therefore decided to rethink the activity to fit in analysis and production as a naturally part of the activity. First the activity starts with a lesson about advertising analysis on a broad scale and the students are then asked to create their own print advertising from newspapers and magazines cuttings. Second phase the students in groups find a few advertisings from the Internet, which they analyse and present for the other students. The last phase involves creating a banner advertising of their own.

The e-commerce activity was created on the basis that the marketers are more and more targeting the youth market and that the age limits for so called "credit cards" will be lowered in the years ahead. Recently in Denmark it has been allowed for banks to issue debit cards to children under 15 years olds as long as the parents agree first. The debit card cannot only be used in 20.000 Danish stores and banks but also to shop on the Internet. The aim with the activity is for young people, 14-16-year olds, to develop skills to become critical consumers on the Internet. They have to learn about consumer and citizen rights and how personal data is permitted / not permitted to be used with a commercial purpose.

The materiel was then adapted according to the expert groups comments and ideas. It resulted in fewer activities since some activities were left out. To constitute the group, we selected two schools in the city Albertslund, which is part the greater Copenhagen area, to test the Educaunet material. 
Next step was to have the material tested on different levels in the Danish "Folkeskole" (primary and secondary school).

Two schools in the city Albertslund, which is part of the greater Copenhagen area, were chosen to test the adapted material :

- Birkelundskolen, which has classes from $1^{\text {st }}$ (age 6-7) to $9^{\text {th }}$ (age 14-15) grade level. This school represents a standard Danish public school

- Det 10 . Element is a school with only $10^{\text {th }}$ grade classes. It has existed a few years and is a rather new concept in the Danish educational system.

The adapted Educaunet material was tested at three different grade levels :

- one $4^{\text {th }}$ grade class - Birkelundskolen : 18 pupils

- one $8^{\text {th }}$ grade class - Birkelundskolen : 20 pupils

- one $10^{\text {th }}$ grade class - Det 10. Element : 15 pupils

The method used to evaluate the testing of material was observations and interviews with teachers and pupils. For the children not to be "disturbed" by their presence, the researchers were first introduced to the class as researchers interested in their use of the Internet. It did not seem as if the researcher's presence caused any disturbance or shyness among the children. Furthermore, immediately after the lessons in which the testing took place, the researchers discussed their impressions of what had happened in the classroom. For these discussions a tape recorder was used. In all the evaluation method has been a question of a triangulation of methods i.e. content analysis, observation, individual and group interviews.

The results of the testing showed that most of the activities worked well with the teachers and students. A few activities we chose after the testing to leave out of a kit of teaching material. The teachers in our experiment were the expert group that had helped us evaluate the original material and they therefore had extensive knowledge about the activities before introducing these to the children. They came into the experiment with their own expectations about the usefulness of the activities but some were actually surprised about the outcome of the testing. As one $4^{\text {th }}$ grade teacher said right after the testing of the tale of Clara in Internetland: "I was very surprised that it opened up for discussion as much as it did...I don't know much about IT and the Internet but it is their world". 
With the activity "Advertising on the Net" the teacher found that the students were very interested in the subject advertising and especially the Net advertising "I think they have been very interested in the subject advertising as a whole. It is something they read and see a lot. I think they (the 8th graders) see it (net advertising) as something that is very close to them... much more than just two years ago, where TV-ads were the big thing. They now spent many hours in front of the computer screen and see it many times".

\section{Future Perspectives}

As has been said above there is a need for teaching materials in relation to the Internet. The Educaunet material is an answer to the need for such material and will hopefully be useful in this connection. However, apart from the introduction of Internet education in the school it is also important to raise a debate among teachers, marketers, parents, politicians and others about children, adolescents and the Internet.

An important aspect regarding Internet education is that the teachers who consider Internet education important highlight the skills and competencies that pupils obtain from this new kind of teaching. These competences are analysis and production skills, autonomy, a critical approach to the Internet and competence in computer and Internet technology and content. Such skills will without a doubt be very useful in the future.

\section{Notes}

1 Center for Marketing Communication, Copenhagen Business School, Denmark 
